\author{
Małgorzata Janiak \\ ORCID 0000-0003-4099-0224 \\ University of Lodz \\ Institute of Urban Geography and Tourism Studies \\ malgorzata.janiak@geo.uni.lodz.pl \\ Monika Kozłowska-Adamczak \\ ORCID 0000-0002-4465-0043 \\ Kazimierz Wielki University in Bydgoszcz \\ Institute of Geography \\ monika.kozlowska@ukw.edu.pl
}

\title{
EVALUATION OF THE MOST POPULAR ACCOMMODATION BOOKING PORTALS WITH REGARD TO CONSUMER AND ACADEMIC USABILITY
}

\begin{abstract}
The hospitality industry is classified as the most fundamental tourism service. As far as the dynamic development of the internet and its constantly growing number of its users are concerned, it seems natural for tourism managers and hoteliers to reach for this particular medium to present their offers and to sell them. Nowadays, the most significant issue for the entire hospitality industry is the broad scope of the global and international booking portals which are the contemporary distribution channels for tourism products and services worldwide. The aim of the following article is to assess the usability and functionality of four booking portals acclaimed on the Polish market (booking.com, hrs.com, hotels.com and hotel.info) with regard to the consumer's (tourist's) point of view and an evaluation of the suitability of this particular source of data for academic research through applying this method to hotels located in five Polish metropolises (Warsaw, Kraków, Łódź, Wrocław and Poznań).
\end{abstract}

Keywords: e-marketing, usability of booking portals, evaluation.

\section{INTRODUCTION}

The constantly increasing expectations and demands of customers, as well as growing competition, have had a powerful impact on hoteliers' exploration for the most effective and efficient methods of remaining on the market or enhancing their positions (WITKOWSKI 2007). Therefore, from 1990, the issue of internet marketing (also known as e-marketing or e-commerce) emerged. At first, the concept concerned simple textoriented websites which offered products or information. However, with the passage of time and developments in the IT sector, they evolved into something more than just a tool for information - they enabled customers' profiles to be obtained and improved the mutual exchange of information (BONICKA \& ANTONOWICZ 2018). Various researchers have highlighted the peculiarity of the hospitality sector claiming that it is obliged to provide information for many recipients simultaneously (SHELDON 1997, WERTHNER \& KLEIN 1999). According to R. LAW (2009), the implementation of IT is crucial for the entire hospitality industry, in particular for managing a company. Already, by 2004, the hospitality sector was considered the most prominent in the economy for transactions that were performed online (WERTHNER \& RICCI 2004). As noted by C.H. MARCUSSEN (2008), the process of online hotel booking is the second largest (after flight ticket booking) in the area of tourism. Since the 1980's, the complex contemporary development of the hospitality industry has been accompanied by the expansion of specialized booking systems (e.g. Amadeus, WorldSpan, Galileo, Sabre) and international accommodation systems that are available for every consumer (ANTONOWICZ 2018), as well as by the development of online travel agencies which assume the role of intermediaries (STANGL, INVERSININ \& SCHEGG 2016, DROZDOWSKA \& DUDA-SEIFERT 2016). As stated by M. BRANNBACK (1997) the role of IT is rising, especially because the products offered and infrastructure are presented electronically. IT no longer performs a supporting role but is the most important factor responding to market demands. Consequently, hoteliers are obliged to maintain a presence on this particular medium and apply technological progress to the entire production process: the formulation of the offer as well as distribution and advertising (BEASZCZUK \& WITKOWSKI 2006). Online sales have become the alternative to traditional 
distribution channels since 2001 and have been effectively applied to the field of tourism (DROZDOWSKA \& DUDA-SEIFERT 2016, p. 7). This is the reason why sales of hotel services, excluding traditional direct selling, have been rising steadily in recent years with the involvement of intermediaries such as booking portals (ANTONOWICZ 2018). According to T. ESCOBARRODRIGUEZ \& E. CARVAJAL-TRUJILLO (2013), online tools are the most convenient way of getting to know the products offered by a particular company and this can result in an improved profit on sales. Online portals, functioning as agents, allow entrepreneurs to draw consumers' attention by 'marketing packages', as well as finding new customers and preparing the sales offer. According to W. ANTONOWICZ (2018), the implementation of well-known intermediaries can result in a competitive advantage in accessing desirable market segments and customers, as well as providing good visibility on the internet (billboard effect). With regard to the economic system, the most important function of the intermediaries is to transform the producers' offer according to the needs of consumers. Tour operators produce modest packages in large quantities, whereas consumers expect a wide range of products in small quantities. In order to meet such expectations, the intermediaries (booking portals) have to purchase large quantities from various sources and divide them into smaller units with a wide range. Therefore, through such action the intermediaries play a major role in adjusting supply and demand and in reducing the amount of labour formerly done by the tour operator and the consumer before a sale and purchase takes place (KOTLER 2002).

E-marketing is applied to implement the main goal of the enterprise, namely achieving profit maximization which presumes an identification of customers' needs and a source of product satisfaction. Such actions are consistent with the philosophy of "perceiving the business from the recipient's point of view" (PRZYBYLAK 2005, p. 257). The issue is quite challenging due to the fact that the number of internet users is constantly increasing: it is estimated that there are over three billion worldwide and nearly 27 million in Poland. While booking a hotel, a statistical user of the internet visits nearly 17 websites and starts the process of browsing a few weeks before the final reservation. However, when the decision about the details of a trip is made, the process is faster and more consistent. The exploration starts on the internet, but is no longer limited to search engines such as Google (www. e-hotelarz.pl/mht/?p=29196), therefore, online marketing is based mostly on structural and functional models. Internet services may be in the form of a horizontal portal (multi-field), or a vertical portal (single-field) oriented towards the publication of as much content as possible. Booking portals have a vertical structure because a maximum surface for the rotational exposure of content is used (the offer of various accommodation facilities). This varies over time and is presented in the form of brief snapshots of content which are located in single or double columns on the home page (https://poradnikprzedsiebiorcy.pl/-marketinginternetowy 0 ).

The development of online booking in Poland began at the turn of the $21^{\text {st }}$ century, however its dynamic growth was noted within the last 10 years. One of the first Polish booking portals was staypoland.com which lost its leading position in favour of odkryjpolske.pl belonging to the tourism office Polish Travel Quo Vadis. Nowadays, according to some hoteliers, the most important Polish booking platform is hotele.pl owned by NetMedia. The hospitality industry began to actively develop in Poland in the second half of the first decade of the $21^{\text {st }}$ century which led to an increase in interest in the Polish national market by representatives of international booking services. Among those platforms, the leading position has been taken by booking.com, established in 1996 in Amsterdam and the first international platform to create a Polish-language version. It is currently the most widely recognized booking service in Poland (https://wwww.e-hotelarz.pl $m h t / ?=14002$ ).

\section{RESEARCH OBJECTIVES AND METHODS}

This article concerns booking portals with regard to their information systems for processing, selecting and integrating the data provided by different sources (websites of hotel facilities) in order to obtain the information necessary to identify the purpose of each system (PIĄDŁOWSKI 2006).

Therefore, the aim is to assess the usability of hotel booking portals from a tourist's perspective (i.e. a person who is searching for useful information about accommodation facilities before beginning a trip) and from the researcher's perspective (i.e. a person collecting solid reliable data for academic analysis). All of the discussion is based on the results of an online investigation (between April and May 2017) searching booking portals for data on the hotel infrastructure of the five Polish largest cities (Warsaw, Kraków, Łódź, Wrocław and Poznań). The basic criterion for this choice was the concept of 'metropolis' which in Poland defines cities of 500000 and more residents (as at 2017). The authors decided to restrict the investigation to hotels since they are considered the most significant and traditional type of accommodation. In addition, hotels are distinguished by their broad range of services provided thus exceeding the sale of accommodation alone in both quantity and quality (HYSKI \& BEDNARZAK 2012). 
Table 1. Assessment criteria (point grading) for selected elements crucial for defining the objective usability of booking portals

\begin{tabular}{|c|c|c|c|c|c|}
\hline \multirow{2}{*}{ Assessment criteria } & \multicolumn{5}{|c|}{ Point scale (number of points) } \\
\hline & 0 & 1 & 2 & 3 & 4 \\
\hline \multicolumn{6}{|c|}{ The first impression a portal makes } \\
\hline Portal aesthetics & very bad & bad & medium & good & very good \\
\hline Overall readability of the portal & very bad & bad & medium & good & very good \\
\hline Presence of an easy-to-use menu & very bad & bad & medium & good & very good \\
\hline \multicolumn{6}{|c|}{ General functions of the portal } \\
\hline The range of general business conditions & very bad & bad & medium & good & very good \\
\hline Price guarantee with a refund & absent & present & $x$ & $x$ & $x$ \\
\hline Flexibility of booking conditions & absent & present & $x$ & $x$ & $x$ \\
\hline $\begin{array}{l}\text { The relationship between the price and the nature of the object and type } \\
\text { of trip (business or leisure) }\end{array}$ & absent & present & $x$ & $\mathrm{x}$ & $\mathrm{x}$ \\
\hline The guarantee of personal data protection and internet connection security & absent & present & $\mathrm{x}$ & $\mathrm{x}$ & $\mathrm{x}$ \\
\hline The possibility of creating a free account on the portal & absent & present & $\mathrm{x}$ & $x$ & $x$ \\
\hline The ability to manage online booking & absent & present & $x$ & $x$ & $x$ \\
\hline The possibility of installing a free mobile application & absent & present & $x$ & $x$ & $x$ \\
\hline Linking the portal to social media (e.g. Facebook, Twitter, etc.) & absent & present & $x$ & $x$ & $x$ \\
\hline $\begin{array}{l}\text { The range of additional services provided via the portal (e.g. purchase } \\
\text { of airline or rail ticket, car rental, TAXI rental, etc.) }\end{array}$ & very bad & bad & medium & good & very good \\
\hline Loyalty packages & very bad & bad & medium & good & very good \\
\hline The possibility of selecting various types of accommodation facilities & absent & present & $\mathrm{x}$ & $x$ & $x$ \\
\hline $\begin{array}{l}\text { Positioning of accommodation facilities according to criteria given by the } \\
\text { customer }\end{array}$ & absent & present & $\mathrm{x}$ & $\mathrm{x}$ & $\mathrm{x}$ \\
\hline E-marketing support for hoteliers & absent & present & $x$ & $x$ & $x$ \\
\hline Offers targeted specifically for groups & absent & present & $x$ & $x$ & $x$ \\
\hline \multicolumn{6}{|c|}{ Practical information for portal users } \\
\hline No fees for booking accommodation through the portal & absent & present & $x$ & $x$ & $x$ \\
\hline Free cancellation of the booking & absent & present & $x$ & $x$ & $x$ \\
\hline The possibility of taking advantage of 'first-minute' offers & absent & present & $x$ & $x$ & $x$ \\
\hline The possibility of choosing your own language version & very bad & bad & medium & good & very good \\
\hline The possibility of choosing the currency yourself & very bad & bad & medium & good & very good \\
\hline $\begin{array}{l}\text { The possibility of choosing the date of stay in the accommodation facility } \\
\text { (even several months in advance) }\end{array}$ & absent & present & $\mathrm{x}$ & $x$ & $\mathrm{x}$ \\
\hline Access to a map with the location of accommodation facilities & absent & present & $\mathrm{x}$ & $x$ & $\mathrm{x}$ \\
\hline The ability to use various information filters & very bad & bad & medium & good & very good \\
\hline Sorting accommodation by room rate per night & absent & present & $x$ & $\mathrm{x}$ & $x$ \\
\hline Sorting accommodation by the number of stars given by the portal & absent & present & $\mathrm{x}$ & $x$ & $x$ \\
\hline $\begin{array}{l}\text { The ability to track the opinions and suggestions of other portal users on } \\
\text { specific accommodation }\end{array}$ & absent & present & $\mathrm{x}$ & $\mathrm{x}$ & $\mathrm{x}$ \\
\hline Ability to give your own assessment after logging in to your account & absent & present & $x$ & $x$ & $x$ \\
\hline $\begin{array}{l}\text { Information on the number of currently available rooms in the } \\
\text { accommodation }\end{array}$ & absent & present & $\mathrm{x}$ & $\mathrm{x}$ & $\mathrm{x}$ \\
\hline $\begin{array}{l}\text { Information on the number of people currently interested in the } \\
\text { accommodation }\end{array}$ & absent & present & $x$ & $x$ & $x$ \\
\hline $\begin{array}{l}\text { Displaying an alert about a reserved room in the accommodation in } \\
\text { a given unit of time (e.g. within a few hours or days) }\end{array}$ & absent & present & $x$ & $\mathrm{x}$ & $\mathrm{x}$ \\
\hline The level of additional information presented on the accommodation & very bad & bad & medium & good & very good \\
\hline $\begin{array}{l}\text { Ranking of the best or most popular accommodation in Poland and in the } \\
\text { world }\end{array}$ & absent & present & $x$ & $\mathrm{x}$ & $\mathrm{x}$ \\
\hline $24 / 7$ telephone service for users & absent & present & $x$ & $x$ & $x$ \\
\hline The answer to frequently asked questions on the portal & absent & present & $x$ & $x$ & $x$ \\
\hline
\end{tabular}

$\mathrm{x}=$ not assessed

Source: authors. 
The investigation was divided into three components. First, specific booking portals were selected, preceded by a diagnostic survey conducted among a group of customers of the tourism market (a sample of 26 students of the Faculty of Tourism and Recreation in Bydgoszcz eager to adopt various new technologies before starting their trips). Their responses allowed further research into the four most popular booking services in Poland (booking.com, hrs.com, hotels.com, hotel.info) which were analyzed with respect to metropolises. The second stage of the research was organized around selecting 'neutral' criteria to attempt an objective and systematic evaluation of these booking portals with regard to usability according to the sample responses. Therefore, the 'point grading' method, which is used effectively in a variety of geographical research, was applied (MATCZAK 1986, WOJCIECHOWSKA 2003, RUNGE 2006). In accordance with the adopted four-point scale (between 0 to 4 ), each booking portal was graded according to 30 criteria, divided into three basic thematic groups (Table 1 ):

- the immediate impression evoked by the portal,

- general functionality of the portal,

- practical information for users of the portal.

Eventually, it was possible to calculate an evaluation ratio ${ }^{1}$ and to designate class divisions (every 25\%), assuming that the division with the lowest values $(0-0.25)$ stands for unusable portals and that with the highest values (0.76-1.00) for significantly usable portals.

The final part of the research focuses on the verification of reliability and credibility of the obtained data (previously evaluated booking portals) in terms of its research value. The content of four portals (booking.com, hrs.com, hotels.com, hotel.info) for hotels located in Warsaw, Kraków, Łódź, Wrocław and Poznań were analyzed according to the accepted criteria for functionality (Table 3). Among the features proposed those were selected which, according to the authors, are objective, universal and most importantly possible for use in a comparative analysis of booking portals. Among them are the criteria that allow a comparison of the size and structure of hotel resources presented on selected booking portals (e.g. the number of hotels in total, numbers from hotel chains, categories of hotel by number of stars, number of hotels by price range).

Special attention has been paid to the criterion of 'location of the accommodation'. It should be understood as the distance (in meters or $\mathrm{km}$ ) in urban space showing its physical location in relation to the administrative centre. Thanks to this, it was possible to separate distances. It was also assumed that the shortest (up to $2 \mathrm{~km}$ from hotel to centre) means the tourist can freely travel on foot, medium range (2.1-5 km) depending on preference - on foot or by public transport, and in the case of the longest (over $5 \mathrm{~km}$ ) the tourism must use collective or individual transport. The last interesting feature is the 'price range between the maximum and the minimum price' of hotel offers. This allows the differentiation of price levels on each booking portal to be tracked according to the time interval accepted for the study, e.g. a specific day or other time period (e.g. weekend). As a result, it is possible to follow current price changes of hotel offers on the market.

\section{EVALUATION OF THE USABILITY OF THE BOOKING SERVICES: SYNTHESIS}

Over recent years, various authors have based their research on issues concerning a variety of services, websites and internet portals, analyzing their usability for different purposes. Some of this research addressed aspects such as assessment of the usability of city websites for the development of tourism (BAŃSKI 2006, GUZIK 2006, PRAŁAT 2011, NOWAKOWSKI 2012) or the reliability of the content available on tourism portals for marketing purposes (DROZDOWSKA \& DUDA-SEIFERT 2016). Therefore, 'web usability' of the portals and websites is defined as the range of usability for specific users that allows implementation of objectives established in accordance with efficiency, effectiveness and satisfaction in particular contexts (NOWAKOWSKI 2012 , p. 44). From this perspective, aspects of usability of hotel booking services have a direct impact on the convenience of use and the ease of access to the information sought by the users. This is applicable not only to the consumers (tourists), but also to the researchers who are searching for interesting data useful for academic analysis. This results from the portals, while providing a service to its users, present information received from their suppliers (accommodation managers). Suppliers, on the other hand, have access to the extranet (internal network within the portals), which produces a constant need to update the data for prices, availability and other information which is displayed by particular platforms (www. booking. com/).

The outcome of the investigation at the very beginning of the research indicated that a vast majority of respondents (ca $80 \%$ ) identified two booking portals as the most popular. It may be assumed that an important part of those, result from e-marketing activities, since for several years the portals have been carrying out successful advertising campaigns not only online but on TV. The first company is the German HRS established in Cologne in 1972 (the owner of hrs.com). At the beginning, the company dealt as an agency in renting hotel rooms for people who travel 
for business and for enterprises. Currently, HRS is the sole provider of accommodation which combines offers of hotels through 'global distribution systems' such as Amadeus, Sabre, Wolrldspan, Apollo, Galileo, Abacus and TravelSky. At the moment, HRS is considered to be the largest provider of hotel services with reference to the number of hotels and the rooms offered (https://hrs.com/). The second most popular portal was the Dutch booking.com - a company which now belongs to Booking Holdings Inc. (NASDAQ: $B K N G)$, the biggest enterprise in the field of online marketing. This is the reason why the portal specializes not only in accommodation booking but also online purchasing of airline tickets and car rental services (www.booking.com/). The remaining responses concerned booking services such as hotels.com with its headquarters in Dallas (Texas, USA), and the German hotel.info that belongs to Hotel.de from Nuremberg.

The assessment of the usability of the four booking portals by the respondents, on the basis the criteria divided into three thematic categories (Table 1), presents those aspects which, as suggested by M. NOWAKOWSKI (2012, pp. 45-46), might be defined as:

1. Information Architecture ( $1^{\text {st }}$ category - first impressions evoked by the portal),

2. Essential content ( $2^{\text {nd }}$ category - overall portal functionality),

3. Usability ( $3^{\text {rd }}$ category - practical information for portal users).

The analysis of the evaluation results (Table 2) carried out demonstrated that the average point grading ratio in all assessments refers only to two divisions: (0.51-0.75) and (0.76-1,00). Therefore, the examined portals are classified as 1) usable in terms of suitability of data and information ( 0.70 for hotel.info and 0.73 for hrs.com) and 2) highly usable in terms of suitability of data and information $(0.82$ for hotels.com and 0.88 for booking.com), respectively. The relatively high usability and transparency of particular portals allows tourists convenient, easy and quick access to a vast range of products and hotel services as well as to undertake appropriate transactions online. Therefore, judging from a marketing point of view, the booking portals are a reliable and practical source of information especially for the market consumer (tourist) who considers the advanced technology of the examined portals as the most appropriate and the fastest route to tourism services.

Recognizing the usability of the data available on the booking portals (in general), the authors decided to the examine this usability for the hotel facilities located in five Polish metropolises (Warsaw, Kraków, Łódź, Wrocław and Poznań) for research purposes.

A thorough analysis of the hotel data base of each of the above cities with reference to these criteria shows that the most significant disadvantage of the presented data is a lack of confidence in the actual standard of the accommodation, with special attention to small and family accommodation or non-branded hotels (i.e. not attached to Polish or international hotel chains and networks). This issue relates mostly to the plethora of guesthouses, motels, small hotels or hostels that are ranked low. The most significant variety was found in Warsaw and Łódź (Table 3). It is a frequent phenomenon that the number of stars given to hotels varies between portals for particular cities. Moreover, the stars might not be in accordance with the official categorization according to the current amendment to the Act of $29^{\text {th }}$ August 1997 on Accommodation services and services of tour managers and guides (DzU 2018, poz. 650) or the Central Statistical Office's (GUS) classification. Such a situation may be perceived as solid ground for accusing the hotelier of misleading the customers. As far as a research perspective is concerned, the question is whether the information on categorization at a particular level on the booking portal is accurate (similar to other tools connected with advertising). M. DROZDOWSKA \& M. DUDA-SEIFERT (2016, p. 13) attempted to answer the question on the basis of a case study of booking.com on accommodation in Wroclaw. The researchers agreed that the level of data reliability concerning categorization of accommodation grows in direct proportion to the standard of the hotel. The highest consistency between sources of information (i.e. data available on the portal compared to the official statistics from Central Statistical Office and Ministry of Sports and Tourism - Central Register of Hotels) occurred for three (or more) star hotels. The same conclusion was made by the authors on the basis of the analysis of the four booking portals for the five Polish metropolises.

Table 2. The results of the evaluation of the usability level of the booking portals: synthesis

\begin{tabular}{|l|c|c|}
\hline $\begin{array}{c}\text { Booking } \\
\text { portals }\end{array}$ & $\begin{array}{c}\text { Total number of } \\
\text { points which the } \\
\text { booking portal } \\
\text { received (N) }\end{array}$ & $\begin{array}{c}\text { Valorisation index } \\
\text { according to the formula } \\
\text { N / Nmax, where } \\
\text { Nmax }=67 \text { points }\end{array}$ \\
\hline Booking.com & 59 & 0.88 \\
\hline Hrs.com & 49 & 0.73 \\
\hline Hotels.com & 55 & 0.82 \\
\hline Hotel.info & 47 & 0.70 \\
\hline
\end{tabular}

Source: authors.

The data analysis shows that the information displayed on the booking portals constantly changes, not only weekly or daily but in real time. The changes concern all of the properties analyzed. The greatest change can be observed for three parameters: 1) the 
Table 3. Variety in size and quality of accommodation according to the Central Statistical Office and booking portals (as at the end of 2017)

\begin{tabular}{|c|c|c|c|c|c|c|c|c|c|c|c|c|c|c|c|c|c|c|c|c|c|c|c|c|c|c|c|}
\hline \multirow{3}{*}{\multicolumn{3}{|c|}{ Assessment criteria }} & \multicolumn{5}{|c|}{ Wrocław } & \multicolumn{5}{|c|}{ Poznań } & \multicolumn{5}{|c|}{ Łódź } & \multicolumn{5}{|c|}{ Kraków } & \multicolumn{5}{|c|}{ Warszawa } \\
\hline & & & \multirow{2}{*}{$\mathrm{CSO}$} & \multicolumn{4}{|c|}{ portal $^{\mathrm{a}}$} & \multirow{2}{*}{$\mathrm{CSO}$} & \multicolumn{4}{|c|}{ portal $^{\mathrm{a}}$} & \multirow{2}{*}{$\mathrm{CSO}$} & \multicolumn{4}{|c|}{ portal $^{\mathrm{a}}$} & \multirow{2}{*}{$\mathrm{CSO}$} & \multicolumn{4}{|c|}{ portal $^{\mathrm{a}}$} & \multirow{2}{*}{$\mathrm{CSO}$} & \multicolumn{4}{|c|}{ portal $^{\mathrm{a}}$} \\
\hline & & & & 1 & 2 & 3 & 4 & & 1 & 2 & 3 & 4 & & 1 & 2 & 3 & 4 & & 1 & 2 & 3 & 4 & & 1 & 2 & 3 & 4 \\
\hline \multicolumn{3}{|c|}{ Number of hotel facilities (total) } & 47 & 58 & 53 & 50 & 53 & 57 & 66 & 50 & 40 & 62 & 31 & 36 & 49 & 29 & 53 & 150 & 152 & 83 & 121 & 144 & 86 & 94 & 95 & 69 & 79 \\
\hline \multicolumn{3}{|c|}{$\begin{array}{l}\text { Number of hotel facilities from hotel } \\
\text { chains }\end{array}$} & n.d. & 13 & 13 & 13 & 13 & n.d. & 13 & 11 & 9 & 10 & n.d. & 10 & 8 & 7 & 10 & n.d. & 26 & 22 & 27 & 30 & n.d. & 38 & 29 & 30 & 32 \\
\hline \multirow{6}{*}{$\begin{array}{c}\text { Hotel } \\
\text { categories } \\
\text { by number } \\
\text { of stars }\left(^{*}\right)\end{array}$} & \multirow{6}{*}{$\begin{array}{l}\text { number } \\
\text { of stars }\left(^{*}\right)\end{array}$} & $5^{*}$ & 7 & 7 & 6 & 7 & 7 & 3 & 3 & 4 & 3 & 3 & 0 & 0 & 0 & 1 & 0 & 10 & 10 & 7 & 11 & 9 & 12 & 12 & 9 & 12 & 10 \\
\hline & & $4^{*}$ & 10 & 13 & 20 & 10 & 10 & 15 & 15 & 12 & 14 & 16 & 6 & 5 & 9 & 10 & 8 & 39 & 41 & 24 & 39 & 41 & 16 & 17 & 24 & 15 & 17 \\
\hline & & $3^{*}$ & 22 & 29 & 24 & 27 & 29 & 29 & 34 & 23 & 19 & 31 & 14 & 16 & 17 & 13 & 18 & 77 & 83 & 43 & 65 & 83 & 34 & 39 & 37 & 32 & 28 \\
\hline & & $2^{*}$ & 4 & 4 & 3 & 5 & 5 & 9 & 11 & 10 & 4 & 11 & 9 & 8 & 9 & 4 & 11 & 16 & 9 & 7 & 5 & 8 & 17 & 16 & 20 & 6 & 19 \\
\hline & & $1^{*}$ & 4 & 3 & 0 & 1 & 2 & 1 & 0 & 0 & 0 & 0 & 2 & 2 & 1 & 1 & 1 & 6 & 3 & 1 & 1 & 1 & 6 & 5 & 0 & 4 & 3 \\
\hline & & $\begin{array}{l}\text { without } \\
\text { category }\end{array}$ & 0 & 2 & 0 & 0 & 0 & 0 & 3 & 1 & 0 & 1 & 0 & 5 & 13 & 0 & 15 & 2 & 6 & 1 & 0 & 2 & 1 & 5 & 5 & 0 & 2 \\
\hline \multirow{4}{*}{\multicolumn{2}{|c|}{$\begin{array}{l}\text { Number of hotels by } \\
\text { price range (in PLN) }\end{array}$}} & up to 150 & n.d. & 7 & 25 & 10 & 17 & n.d. & 18 & 13 & 11 & 27 & n.d. & 3 & 29 & 8 & 16 & n.d. & 32 & 11 & 10 & 24 & n.d. & 0 & 10 & 8 & 23 \\
\hline & & $151-300$ & n.d. & 36 & 13 & 33 & 32 & n.d. & 22 & 31 & 26 & 34 & n.d. & 16 & 17 & 17 & 30 & n.d. & 63 & 28 & 56 & 89 & n.d. & 13 & 54 & 34 & 30 \\
\hline & & $301-500$ & n.d. & 13 & 13 & 6 & 3 & n.d. & 15 & 1 & 3 & 1 & n.d. & 5 & 2 & 2 & 4 & n.d. & 41 & 30 & 37 & 23 & n.d. & 35 & 17 & 13 & 15 \\
\hline & & $\begin{array}{c}\text { more } \\
\text { than } 501\end{array}$ & n.d. & 2 & 2 & 1 & 1 & n.d. & 11 & 5 & 0 & 0 & n.d. & 12 & 1 & 2 & 3 & n.d. & 16 & 14 & 18 & 8 & n.d. & 46 & 14 & 14 & 11 \\
\hline \multirow{4}{*}{$\begin{array}{c}\text { Price range } \\
\text { between } \\
\text { the max. } \\
\text { and min. } \\
\text { price of } \\
\text { offer } \\
(\mathrm{PLN})^{\mathrm{c}}\end{array}$} & \multirow{2}{*}{ 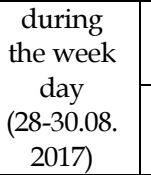 } & $\min$. & n.d. & 211 & 159 & 168 & 88 & n.d. & 192 & 198 & 232 & 206,4 & n.d. & 140 & 80 & 171 & 80 & n.d. & 180 & 187,2 & 198 & 169,2 & n.d. & 198 & 115 & 260 & 129 \\
\hline & & max. & n.d. & 2000 & 576 & 1398 & 1012 & n.d. & 1980 & 928,8 & 1900 & 816 & n.d. & 856 & 400 & 895 & 396 & n.d. & 2900 & 2473,9 & 2419 & 2610 & n.d. & 2365 & 888 & 3240 & 2057,4 \\
\hline & $\begin{array}{l}\text { during } \\
\text { the week- }\end{array}$ & $\min$. & n.d. & 180 & 271 & 185 & 88 & n.d. & 240 & 220 & 325 & 280 & n.d. & 140 & 80 & 178 & 88 & n.d. & 178 & 178,2 & 200 & 178,2 & n.d. & 220 & 95 & 304 & 150 \\
\hline & $\begin{array}{l}(15-17.09 . \\
2017)\end{array}$ & $\max$ & n.d. & 2000 & 499 & 3385 & 666 & n.d. & 1718 & 1222 & 2142 & 763 & n.d. & 817 & 500 & 806 & 376 & n.d. & 2415 & 3550 & 3550 & 1948 & n.d. & 3752 & 2376 & 3821 & 1690 \\
\hline & & up to $0.5 \mathrm{~km}$ & n.d. & 13 & 19 & 13 & 13 & n.d. & 20 & 5 & 8 & 9 & n.d. & 7 & 7 & 5 & 3 & n.d. & 24 & 19 & 31 & 29 & n.d. & 8 & 5 & 4 & 2 \\
\hline & & $0.6-1.0 \mathrm{~km}$ & n.d. & 9 & 8 & 8 & 9 & n.d. & 10 & 10 & 10 & 9 & n.d. & 5 & 6 & 1 & 10 & n.d. & 37 & 17 & 25 & 29 & n.d. & 12 & 12 & 12 & 1 \\
\hline Distance fron & the city & $1.1-1.5 \mathrm{~km}$ & n.d. & 8 & 4 & 9 & 9 & n.d. & 9 & 2 & 4 & 6 & n.d. & 4 & 15 & 6 & 8 & n.d. & 23 & 10 & 20 & 25 & n.d. & 13 & 6 & 8 & 5 \\
\hline & & $1.6-2.0 \mathrm{~km}$ & n.d. & 6 & 1 & 2 & 1 & n.d. & 3 & 4 & 1 & 1 & n.d. & 2 & 5 & 6 & 10 & n.d. & 9 & 8 & 8 & 7 & n.d. & 4 & 8 & 6 & 11 \\
\hline & & $2.1-5.0 \mathrm{~km}$ & n.d. & 13 & 11 & 12 & 12 & n.d. & 16 & 17 & 12 & 21 & n.d. & 7 & 9 & 4 & 13 & n.d. & 40 & 16 & 27 & 33 & n.d. & 15 & 10 & 8 & 24 \\
\hline & & $\begin{array}{l}\text { more than } \\
5,1 \mathrm{~km}\end{array}$ & n.d. & 9 & 10 & 6 & 9 & n.d. & 8 & 12 & 5 & 16 & n.d. & 11 & 7 & 7 & 9 & n.d. & 19 & 13 & 10 & 21 & n.d. & 42 & 54 & 31 & 36 \\
\hline
\end{tabular}

Explanation:

a The individual numbers correspond to booking portals: 1 - booking.com; 2 - hrs.com; 3 - hotels.com; 4 - hotel.info; n.d. - no data.

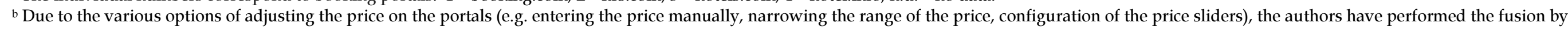
determining class compartments which are identical and comparable.

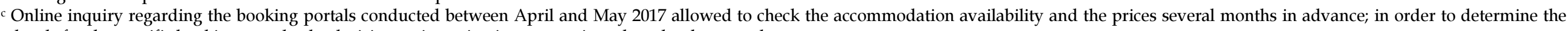
price levels for the specific booking portals, the decision on investigation two various dates has been made.

Source: own study based on field research and data from the Central Statistical Office (2017). 
sole availability of guest rooms in particular hotels on the date given (data variation in real time); 2) the level of declared prices for accommodation in particular hotels; 3 ) the overall number of hotels according to price ranges adopted to the analysis (daily data variation). Declared prices change depending on the date (or hour) of data generation. Moreover, current promotions and discounts offered at the specific time of browsing are displayed which influences the general fluctuation of the number of accommodation facilities according to that particular criterion. However, the crucial fact is that the person (tourist) who wants to book a guest room on particular dates (e.g. 28 ${ }^{\text {th }}-30^{\text {th }}$ August 2017) via the booking portal (intermediary) has an assurance that the contracted price remains constant on the basis of the date of purchase or regulations included in terms and conditions of particular booking portal (www.hrs.com/ web3/ showCmsPage.do? clientId=cGxfX05FWFQ-Ecid=63-4E $p a$ geId=standard02217). Therefore, the above situation is certainly functional and practical for the customer. Although, for academic research, this particular type of data shows rapid fluctuations in short periods of time and can distort the results.

An attempt to evaluate the size of the hotel infrastructure (in general) for metropolises using the booking portals, requires highlighting the statistical discrepancies between data provided by Central Statistical Office and the data available on the booking portals of particular cities. This results in interpretative difficulties. Discrepancies for various portals are depicted as follows: booking.com - $109 \%$ to $123 \%$, hrs.com - 55\% to $168 \%$, hotels.com $-70 \%$ to $106 \%$ and hotel.info $-92 \%$ to $171 \%$, which means that the number of hotels in particular cities varies and is very often considerably inflated in relation to the official source. This is exemplified by:

- Wrocław - discrepancies vary from 50 hotels (hotels.com) to 58 (booking.com) in relation to the 47 declared

- Łódź - from 29 hotels (hotels.com) to 53 (hotel. info) in relation to the 31 declared.

On the other hand, the opposite trend might be observed as well. It is best illustrated by the example of Kraków where, according to official statistics (as at the end of 2017), there are 150 hotels located within the city. However, the number of hotels available on the portals is definitely smaller, varying between 83 (hrs.com) to 144 (hotel.info), a discrepancy of 55-96\%. According to the authors, the situation might be explained by the fact that the hotelier is the sole provider of the service bears the costs for every reservation. The commission for booking portals varies between $12 \%$ and $30 \%$ of the final price of the service (ANTONOWICZ 2018) depending on the level of implementation of the tools of e-marketing for promo- tion and distribution of the hoteliers' offers. The problem of commission concerns mostly smaller hotels and family guest houses as well as those with a lower classification and only a tentative position on the market as well as those that do not belong to hotel networks and chains.

The most beneficial data derived from the booking portals for all metropolises is the detailed location with information about distance to the city centre. According to the authors, this particular data, after appropriate analysis, might be presented in form of the spatial range of the hotels. Again, the problem of the exact numbers of hotels appears. However, it becomes evident that an analysis of the type of hotel faciity allows discussion on the role of the concept of ground rent in large cities. The examples analyzed here show that the further from the city centre, the higher the number of smaller and cheaper hotels (including those with a lower number of stars). On the other hand, location at the heart of the city (maximum of $1.5 \mathrm{~km}$ ) can be afforded mostly by international (e.g. Mercure, Novotel, Holiday Inn) and national hotel chains (Diament Hotels, Gromada, Focus Hotels). Special circumstances can be observed in Warsaw, probably due to the capital function of the metropolis and the existence of the largest airport in Poland within the city. A thorough analysis of the data collected from various booking portals confronted with the real location of the hotels demonstrates that the density is highest in the northern parts of Warsaw. On the other hand, the central parts are dominated by premium apartments or so-called apartment hotels (with the exception of a few examples from lower categories: 2-star Ibis Warszawa Centrum, 3-star Campanile, 4-star Golden Tulip).

\section{CONCLUSIONS}

E-marketing is the vital element of the modern hotel promotion. Booking portals are a tool for:

- producers of accommodation services in order to extend the market coverage of the company (spatial approach) and to implement new distribution channels through online sale; on the other hand, booking portals allow new segments of the market to be reached, i.e. customers who willingly use modern technologies (the internet) before starting journeys;

- a consumer (tourist) to simplify the process of choosing the best accommodation and to shorten the time needed for finding it; the search occurs by inserting information about destination, date and additional features of the trip and in a few moments the best offer corresponding to the criteria appears; the 
customer receives the offer prepared by various hoteliers in one place.

Evaluation shows that the most popular booking portals in Poland (booking.com, hrs.com, hotels.com and hotel.info) have relatively high level of usability of the available data and information (evaluation ratio of 0.70 and more), especially with regard to customers. The growing expectations and requirements of tourists should be met by the practicality and functionality of the portal - defined by three aspects: 1) architecture of the available information, 2) essential content, and 3) usability for users. Therefore, the most popular booking services allow the consumers to reach the best accommodation in an easy and quick manner and to inform them about the existence of accommodation in various price ranges and at various levels of quality gathered in one place.

Information presented on the booking services on hotels located in the five Polish metropolises (Warsaw, Kraków, Łódź, Wrocław and Poznań) undergoes constant change noticeable in real time. This means that the comparison of some quantitative data (e.g. the number of the hotels and their categorization) collected from the portals is relatively difficult and requires additional procedural algorithms for research purposes. However, the value of the examined portals is defined by access to a variety of qualitative data, both on a general level (functionality of the service) and on accommodation facilities. According to the authors, the data allows a partial analysis to be undertaken attempting to define the potential trends and tendencies of hotel development in particular cities, with regard to:

- the supply of hotel brands (international and national hotel chains and networks) that exists mostly within the territories of particular cities,

- availability of ground rents for new hotels in the city,

- price availability of hotels for various segments of the tourism market.

All things considered, the qualitative and quantitative variety of data on hotels accessible on the booking portals results in an increase of their usability (not only in marketing terms). Their number is definitely higher than the official data of the Central Statistical Office (which is limited only to the size and type of accommodation). According to the authors, despite a few weaknesses, the content available on the booking portals should be employed for academic research and perceived as a valuable source of information that complements the official statistics. This is because 'UGC applications ${ }^{2}$ allow insight into the detailed description of services and devices offered by the hotels while the official statistical data provide only overall or incomplete information' (DROZDOWSKA \& DUDASEIFERT 2016, p. 13).

\section{ENDNOTES}

${ }^{1}$ Evaluation ratio - number of points obtained through the evaluation of all the characteristic features of the specific booking website $(\mathrm{N})$ / maximum number of points available for that criterion $\left(\mathrm{N}_{\max }\right)$.

2 User-generated content (UGC) - all of the users of a given platform may become an active part in the exchange of information (Constantinides 2009, in: DROZDOWSKA, DUDA-SEIFERT 2016, p. 9).

\section{BIBLIOGRAPHY}

ANTONOWICZ W., 2018, Jak odpalić biznes hotelowy w Internecie - sześć kroków, [in:] ABC inwestycji hotelowych. Raport Magazynu Hotelarz, Polskie Wydawnictwa Specjalistyczne ProMedia, Warszawa, pp. 48-50.

BAŃSKI J., 2006, Witryny internetowe jednostek samorządowych z siedzibą w małych miastach - analiza i ocena, Studia Obszarów Wiejskich, v. 11: Rola matych miast w rozwoju obszarów wiejskich, pp. 59-72.

BŁASZCZUK W., WiTKOWSKI C., 2006, Hotelarstwo w Polsce. Wybrane zagadnienia, Wyd. Akademickie WSSP im. Wincentego Pola w Lublinie, Lublin.

BONICKA J., ANTONOWICZ W., 2018, Inteligentne, sprofilowane systemy przetwarzania danych, [in:] Economy \& technology $\mathcal{E}$ marketing trends 2018, Wyd. Profitroom, Poznań, pp. 34-35.

BRANNBACK M., 1997, Is the Internet changing the dominant logic of marketing?, European Management Journal, 15, 6, pp. 698-707.

DROZDOWSKA M., DUDA-SEIFERT M., 2016, Travel websites: A relevant source of statistical information?, Turyzm/Tourism, 26, 2, pp. 7-13.

ESCOBAR-RODRÍGUEZ T., CARVAJAL-TRUJILlo E., 2013, An eevaluation of Spanish hotel websites: Informational vs. relational strategies, International Journal of Hospitality Management, 33, pp. 228-239.

GUZIK R., 2006, Gminy w Internecie, [in:] B. Domański, W. Jarczewski (eds.), Klimat inwestycyjny w województwie matopolskim, Departament Gospodarki i Infrastruktury Urząd Marszałkowski Województwa Małopolskiego, Kraków, pp. 75-79.

HYSKI M., BEDNARZAK J., 2012, Funkcje hotelarskie zabytkowych obiektów zamkowych, Wyd. Akademia Wychowania Fizycznego im. Jerzego Kukuczki w Katowicach, Katowice.

KOTLER P., 2002, Marketing. Podręcznik europejski, Polskie Wydawnictwo Ekonomiczne, Warszawa.

LAW R., 2009, Disintermediation of hotel reservations: The perception of different groups of online buyers in Hong Kong, International Journal of Contemporary Hospitality Management, 21, 6, pp. 766-772.

MATCZAK A., 1986, Przyrodnicze podstawy organizacji wypoczynku w strefie podmiejskiej Łodzi, Acta Universitatis Lodziensis. Turyzm, 2, pp. 25-45.

MARCUSSEN C.H., 2008, Trends in European internet distribution - of travel and tourism services. Trends in European internet distribution - of travel and tourism services, http://195.130.87. 21:8080/dspace/handle/123456789/864?mode=full\&submit _simple=Show+full+item+record; 17.10.2018.

NOWAKOWSKI M., 2012, Użyteczność oficjalnych serwisów internetowych miast na turniej EURO 2012, Zeszyty Naukowe Uniwersytetu Szczecińskiego. Studia Informatica, 29, pp. 43-56, ISSN 0867-1753, ISSN 1640-6818. 
PIĄDŁOWSKI K., 2006, Portale internetowe, Centrum Edukacji Bibliotekarskiej, Informacyjnej i Dokumentacyjnej im. Heleny Radlińskiej w Warszawie, Warszawa.

PRAŁAT E., 2011, Badania witryn internetowych polskich gmin, Zeszyty Naukowe Uniwersytetu Szczecińskiego, Ekonomiczne Problemy Ustug, 67, pp. 564-571.

PRZYBYLAK D., 2005, Znaczenie marketingu w usługach turystycznych, [in:] W. Siwiński, R.D. Tauber, E. Mucha-Szajek (eds.), Hotelarstwo, rekreacja, turystyka. Kierunki przemian $w$ świecie postindustrialnym, Wyd. WSGiH w Poznaniu, Poznań, pp. 256-266.

RUNGE J., 2006, Metody badań w geografii społeczno-ekonomicznej - elementy metodologii, wybrane narzędzia badawcze, Wydawnictwo Uniwersytetu Śląskiego, Katowice.

SHELDON P.J., 1997, Tourism information technology, CAB International, Wallingfort.

STANGL B., INVERSINI A., SCHEGG R., 2016, Hotels' dependency on online intermediaries and their chosen distribution channel portfolios: Three country insights, International Journal of Hospitality Management, 52, pp. 87-96.
Ustawa z dnia 29.08.1997 r. o ustugach hotelarskich oraz ustugach pilotów wycieczek i przewodników, DzU 2018, poz. 650.

WERTHNER H., RICCI F., 2004, E-commerce and tourism, Communitation of the ACM, 47, 12, pp. 101-105.

WERTHNER H., KLEIN S., 1999, Information technology and tourism, Springer Verlag Vien, Vien.

WITKOWSKI Cz., 2007, Hotelarstwo, part 1: Podstawy hotelarstwa, Wyd. Almamer, Warszawa, pp. 261.

WOJCIECHOWSKA J., 2003, Analiza i ocena zagospodarowania turystycznego, [in:] S. Liszewski (ed.), Możliwości i kierunki rozwoju turystyki w Dolinie Odry, Katedra Geografii Miast i Turyzmu UŁ, Łódzkie Towarzystwo Naukowe, Łódź, pp. 136-156.

http:/ / www.e-hotelarz.pl/mht/?p=29196.

https://pl.hotels.com/.

https:// poradnikprzedsiebiorcy.pl/-marketing-internetowy0. https://www.booking.com/.

https://www.e-hotelarz.pl/mht/?p=14002.

https://www.hotel.info/.

https://www.hrs.com/.

Article received:

31 August 2018

Accepted:

10 October 2018 